\title{
Forster's Tern Sterna forsteri
}

Habitat Preference: Large prairie wetland complexes. Nests are built on muskrat houses, floating cattail rootstocks, or on piles of floating vegetation.

\section{Threats:}

- Loss of wetland habitat

- Many natural wetlands have been drained throughout lowa and specifically in the Prairie Pothole Region for

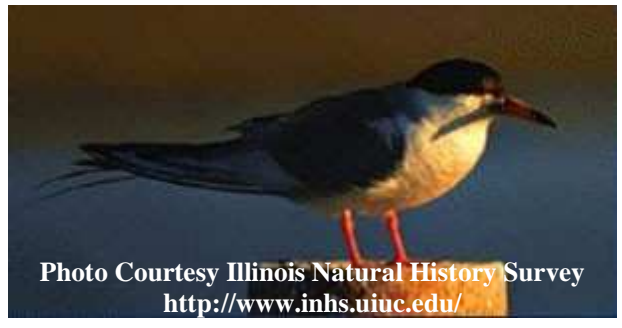
agricultural practices.

- Inappropriate wetland restoration

- Recent restorations seem to favor cattails and other emergent vegetation. This type of restoration will not be used by Forster's Terns.

- Forster's Terns do not seem to use areas that have regular water level manipulations due to the emergent vegetation that results.

- Many basins that have been restored are too small to be used by Forster's Tern. They use areas of greater than 20 hectares (54 acres) of restored basins.

- Age of restored wetlands may be a significant factor

- Forster's Terns are a late succesional wetland species. Newly restored wetlands do not attract Forster's Terns.

\section{Practice Guidelines:}

- Restore Wetlands:

- Important to restore natural wetland areas.

- These areas need to have a considerable amount of open water. Forster's terns prefer wetlands with relatively equal components of open water and emergent vegetation, with the emergent vegetation interspersed throughout the open water.

- Keep adequate stable water levels through the nesting season.

- Restored wetlands should be greater than 20 hectares (54 acres).

- Control monotypic stands of cattails

- Forster's terns prefer not to use wetlands with dense stands of cattails.

- These stands can be controlled with herbicide, removal of cattails, and with muskrat populations.

- Manage for tern nest sites

- Dead floating cattail mats are attractive tern nest sites, as are old muskrat houses. When other nest sites are lacking, artificial nesting structures can be used with some success.

- Preserve existing wetlands

- Forster's Terns seem to prefer to nest in a natural occurring wetland rather than a restored wetland. 